\title{
The Application of Let's Read! in Extensive Reading Class: Integrating MALL and Task-based Learning
}

\author{
Anesti Budi Ermerawati \\ Universitas Kristen Duta Wacana, Yogyakarta, Indonesia \\ $\bowtie$ ermerawati@staff.ukdw.ac.id
}

\begin{abstract}
Doing national program so called School Literacy Movement (GLS), classes are expected to do 15-minute regular reading activity every day; including English classes in elementary schools. Witnessing that some classes are having limited English story books to read as well as ready-to-use follow-up activities, this article proposes reading activities using ebook application Let's Read! that can be applied after the regular reading activities. Ranging from the low leveled-books to the advanced ones, the proposed activities in this extensive reading class are integrated; combining tasks that require children to experience Mobile Assisted Language Learning (MALL) as well as having both individual and group offline work. This type of reading activity promotes L2 learner language development, increases their motivation in reading, and helps them build reading habits. At the same time, the alpha generation maximizes the use of technology to get themselves updated with the changing use of online applications such as Let's Read!
\end{abstract}

Keywords: Digital Library, Extensive Reading, GLS, Task-Based Learning

How to Cite: Ernawati, A. B. (2019). The Application of Let's Read! in Extensive Reading Class: Integrating MALL and Task-based Learning. Mimbar Sekolah Dasar, Vol. 6(3), 317-329. doi:http://dx.doi.org/10.17509/mimbar-sd.v6i3.20870

INTRODUCTION It has been four years since the Permendikbud No. 23 of 2015 initiating the government action towards students' low reading habit, which is known as School Literacy Movement (GLS - Gerakan Literasi Sekolah). The Department of Primary and Secondary Education reported that based on their research in the international assessment in 2015 called PISA (Programme of International Student Assessment), Indonesian students' literacy competence, particularly in the fields of reading, writing, science and arithmetic, achieved unsatisfactory results. The government policy then promotes the 15-minute reading activity every day before a class starts studying in order to give the students exposures on reading activities. The regular reading activity is believed to begin students' reading habit as they need it for their lifelong learners.

The literacy movement plays important role in the country as it works on building students' literacy competence. Therefore, schools are suggested to not only carry out the 15-minute reading every day, but they also need to integrate the activity of reading in the lessons. According to Faizah et al. (2016), the activity of reading for 15 minutes promotes two benefits, namely increasing new vocabulary items, and 
Anesti Budi Ermerawati, The Application of Let's Read! in Extensive Reading Class...

providing extensive reading for the students. They illustrate that by doing regular 15-minute reading, a student reaches 5,475 minutes of reading in a year, which means that there are 1 million words can be exposed. Vocabulary mastery is a component for a student to comprehend a passage (Scarborough, 2001; Trelease, 1997). The more a student reads, the more he understands different types of passages, and at the end, he communicates both in better spoken and written.

\section{LITERATURE REVIEW}

In this part, the role of extensive reading for English language learners, the relationship between $Z$ generation and MALL, as well as task-based extensive reading will be explored. In addition, the description of Let's Read! App and how it supports an extensive reading class in elementary school are also elaborated.

\section{Extensive Reading for English Language Learners}

Regular reading activity triggers the students' habit of reading. Trelease (1997) stated that human being, first of all, is doing what they like most the most. A person is doing physical exercise several times, while enjoying and getting benefits from doing this hobby. In line with that idea, the activity of reading will become student's habit, if it becomes a pleasurable activity for him. The second fact is that to become readers, students need a process of reading practice; as someone who is practicing how to drive or how to sew. Therefore, setting the students in an extensive reading class brings them to an enjoyment of reading, which may help them to get through the stages of being willing to read, understanding their books, and love reading.

Day \& Bamford (1998) explain that extensive reading increases student's confidence, better learning, and their ultimate goal, student will be a real reader as he has grown up. Furthermore, as reading for pleasure becomes a student's habit, his academic achievement will show good progress. In 2016, Progress in International Reading Literacy Study stated that a student with reading-for-pleasure habit shows a better academic progress compared to those who read for studying the lessons being tested. The finding is supported by Elley (1991) who said that those children who are exposed to story books extensively, and invited to read and share them, are found to learn the target language faster. When meaningful books are brought to them without feeling anxious about grammar and vocabulary, these young language learners happen to acquire the language accidentally, and then they eventually show positive attitudes towards story books.

Extensive reading can be described as independent reading that focuses on the number of materials dedicated for finding information or pleasure (Bamford, 1998). The idea of conducting extensive reading program in English classes is to make 
students read sources in target language and like them. Bamford (1998) suggests teachers to apply the key activities for a successful extensive reading class, which are (1) students read big numbers of printed material, (2) students read various topics and genres, (3) students' reading materials are within their level of comprehension, (4) students decide what they want to read, (5) students read for pleasure, information, and general understanding, (6) teachers read with their students, to be role models of good readers, and (7) teachers guide and keep track of student's progress.

Extensive reading lets the students decide their preferred levels and genres of books. This process allows them to increase their motivation to read plenty of books. According to an interview to Paul Nation held by Iswandari and Paradita (2019), Nation shared that students who are exposed to plenty of readings are having good readiness towards $L 2$. In their future, they will have a good English proficiency to support them to have good careers.

\section{Z Generation and MALL}

Mobile assisted language learning (MALL) is widely known as a branch of studyenhancing technology, which can be applied in some kinds of learning modes. MALL is a learning approach that utilizes mobile phones to make a more challenging and up-to-date learning process for learners. Current learners are known as 'digital natives' (Prensky, 2007) or the 'net generation' (Oblinger, 2003).
Since they have been smartphones active users, learners find it interesting when they are asked to use personal mobile phones for school-centered learning activities. Kirkwood (2008) responded that many institutions are now trying to conduct different teaching and learning process by applying MALL, encouraging lifelong learning, and extending the participation of 'non-traditional' students. The nature of education must change in order to accommodate the skills and the interests of the new generation (Prensky, 2007). In the past, books and educators were the most frequent sources of information. Poláková \& Klímová (2019) assume that huge change has happened in the process of learning in the classrooms, because the Generation $\mathrm{Z}$ uses technology over books, and the students expect this to survive the education process as well. Regarding this, teachers must improve their teaching method, and make the learning environment more appropriate to $21^{\text {st }}$ century students.

Kondo (2015) elaborated that besides the technology application that is recommended in classrooms, teachers also need to focus on learners' selfregulation, which requires integrated micro-processes, including goal-setting, strategic planning, the use of effective strategies to organize, code, and information storage. In line with Kondo, Jones (1998: 378 ) stated that MALL boosts learners' self-study in the long term, which is defined as "a deliberate long-term 
Anesti Budi Ermerawati, The Application of Let's Read! in Extensive Reading Class...

learning project instigated, planned, and carried out by the learner alone, without teacher intervention".

This trend is certainly important to be considered by teachers to accommodate the learners' being technology active users, so that teachers should take a fearless attitude in the use of technology, ask ourselves how to conquer these disadvantages, develop full potential of technology in our instruction as learners' facilitators and guide them to become lifelong learners. Other research has found that the brains of Generation $Z$ are structurally different to those of previous generations. This is the result of how our brains are used to respond to our environment. Generation Z has linked themselves to sophisticated, complex visual imagery. Hence, the part of the brain responsible for visual ability is far more developed, which resulting in visual forms of learning being more effective. This generation of student favors interactive games, collaborative projects, experiments, challenges, and anything that can be tried or seen.

\section{Task-Based Extensive Reading}

Since task provides opportunities for students to get both input and output, which are essential for their L2 development, teachers need to design interesting and useful tasks taken from the books the students read. Freeman (2003) supports that a task-based approach provides a natural context for language use. Meaningful tasks, such as opinion exchange tasks, retelling the story, playing roles, and producing written works or giving oral presentations to the whole class, are involving the students to be actively speak and write in L2. At the same time, students will also gain the skills required in this $21^{\text {st }}$ century learning, namely collaboration and communication. When they complete a task, they have many opportunities to interact with peers. This condition puts language acquisition in which students have to strive to understand each other, and to deliver their own meaning. By collaborating and communicating, they are able to listen to language which may be beyond their current ability, yet which may be related to their knowledge of their target language in the future. It is in line with Candlin and Murphy (1987) who stated that when a problem-solving negotiation takes place between students' knowledge and new knowledge, a real language learning occurs.

Because the purpose of reading the material is to assist the completion of tasks, some follow-up activities are offered to involve students in using language to express their personal perspective on the reading. It is suggested that extensive reading in a task-based approach is recommended for language learners, because, it does not only facilitate the development of specific reading skills (e.g. reading fluency) and critical thinking skills (e.g. reasoning ability), but it also promotes learning through interaction (Green, 2005). 
Green's ideas are aligned with the 4C's century skills, namely critical thinking, creativity, collaboration and communication. As global citizens, students need to improve their life skills, such as being competent in reading, writing, arithmetic, and science, applying the skills for living, having awareness on financial issues, and to be literate global citizens. Therefore, students need to be exposed to tasks that require critical thinking, collaboration, effective communication, and creative solutions.

Seeing the needs of the millennials to actualize themselves in this digital era, teachers are suggested to provide reading sources that impress the students to read more. Cho and Krashenuns (2019) support the importance of interesting readings:

Before we rush off to invest in expensive and uninvestigated technology, we need to make sure our students have access to interesting and comprehensible reading materials (p.5)

\section{Let's Read Application}

Relating to reading materials using gadgets in a classroom, one of Android

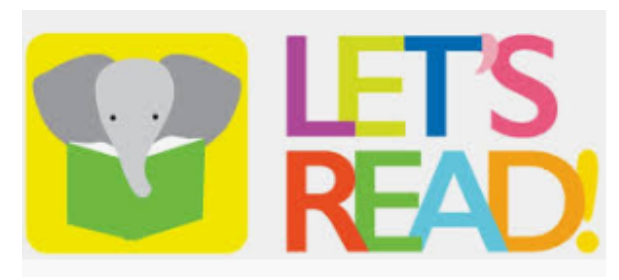

Figure 1. Let's Read! Mobile Application applications, which is called Let's Read! provides collections of graded reading materials that can be accessed through any students' mobile phones under adult supervisions. Overcoming book scarcity in Asia, Let's Read! established by The Asia Foundation composes and translates children digital books. The collaboration among local authors, illustrators, and editors to produce high quality books containing unsupported languages provides more chances for Asian children to have enough or even more reading exposures using their gadgets. Classroom teacher can use any gadgets, such as smartphones or classroom's PC and projector.

Supporting the core of extensive reading, this application cultivates meaningful reading opportunities, so that children, especially who are learning English as a foreign language, may get their reading level, and the most important is that they can explore the stories, because local stories are presented in Let's Read! collections. It is one of the attempts to let these young readers explore important topics, such as equality, diversity, and environment. Another social goal issued by Let's Read! action is that both children and their families are able to obtain positive impacts from reading stories in Let's Read!, for example, children who love reading are more likely to enjoy learning, succeed in school, and reach developmental milestones on time. Families who read together create rituals and a shared sense of belonging that supports positive behavior. Further, children readers become adult readers who are able to care for themselves and their 
Anesti Budi Ermerawati, The Application of Let's Read! in Extensive Reading Class...

families, and contribute to thriving societies.

\section{THE PRACTICAL USES OF LET'S READ! IN A TASK-BASED EXTENSIVE READING CLASS}

GLS is applied gradually in primary school classes. As the program sets a long-term goal, it proposes three steps to reach its success, which makes the students truly readers. The three steps, namely habituation, development, and learning, are not only applicable in Indonesianbased lessons, but also in English language classes. Krashen (1993: 23) said that reading is the only way language learners to become good readers, develop a good writing style, an adequate vocabulary, advanced grammar, and the only way they become good spellers.

According to Green (2005), extensive reading in a task-based approach provides a reading purpose for language learners, and offers opportunities for learners to practice language, the present study proposes the implementation of taskbased extensive reading in the 15-minute regular reading activity in primary schools as proposed by GLS program. The graded readers from Let's Read! mobile application are chosen as they are specifically written for language learners and the content is adapted to match the language level of learners.
The proposed weekly task-based extensive reading activity consists of two stages: in the first stage, the whole class read teacher-selected digital book, and in the second stage, individual students read selfselected digital books. The suitable levels of students for this type of activities are the 4-6 graders as the characteristics of children aged 10-12 are able to learn how to collaborate with other students, particularly in groups, and they like writing notes to each other, and creating skits and participating in role plays. Like children in younger grades, they continue to obtain advantages from imaginative and creative play, and they also like a story that has a definite beginning, middle, and end (Piaget, 1963). However, the lower levels of the students may have similar activities that are simplified.

To get a right level of the graded readers in Let's Read! App, firstly students need to install the application in their gadgets (Fig. 2). After getting to the homepage, teacher then needs to help the students to set the language into English, and the levels of the book (Fig. 3\&4). Introducing the learners to the people behind the particular digital book on the cover page (fig. 5) is also a good reading habit to nurture. On the prediction page (Fig. 6), The students are invited to predict the story, and have discussion on it before they come to the story page (Fig. 7). 


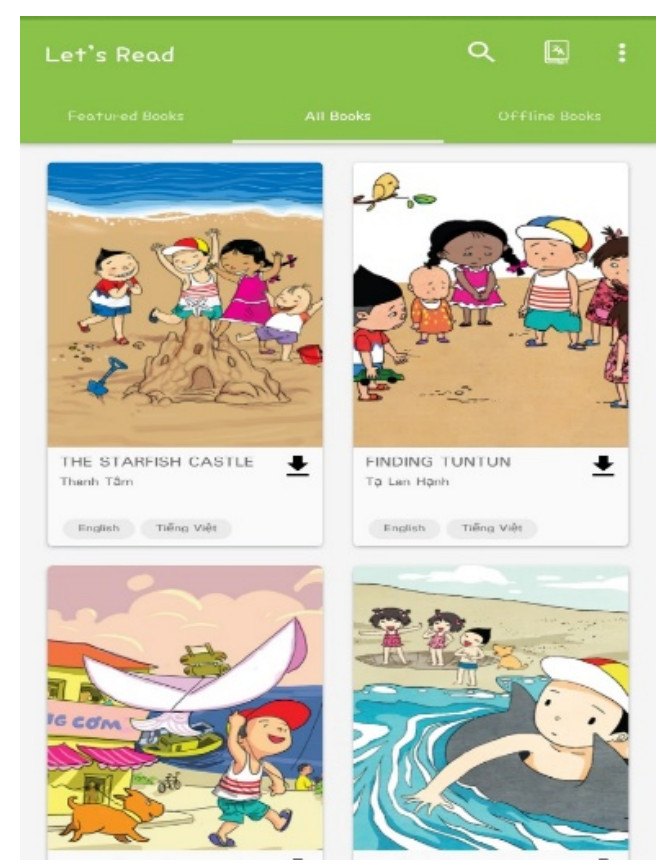

Figure 2. The Homepage

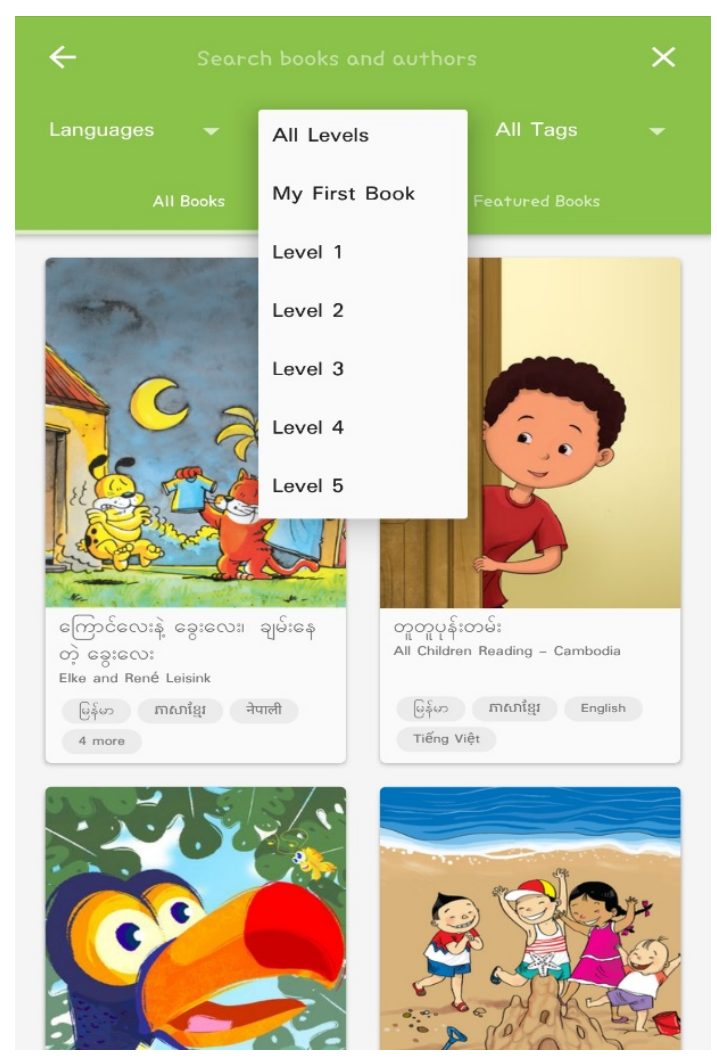

Figure 4. Level Setting

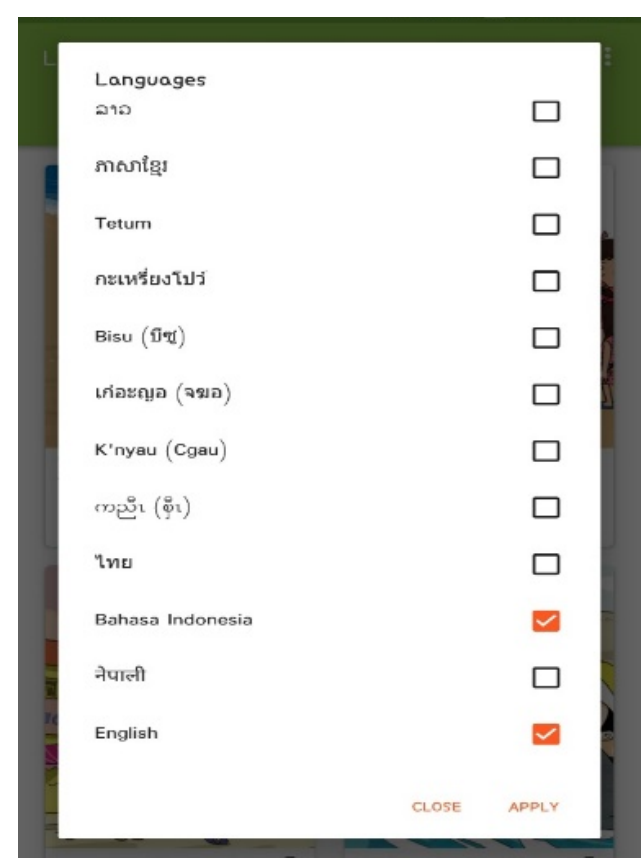

Figure 3. Language Setting

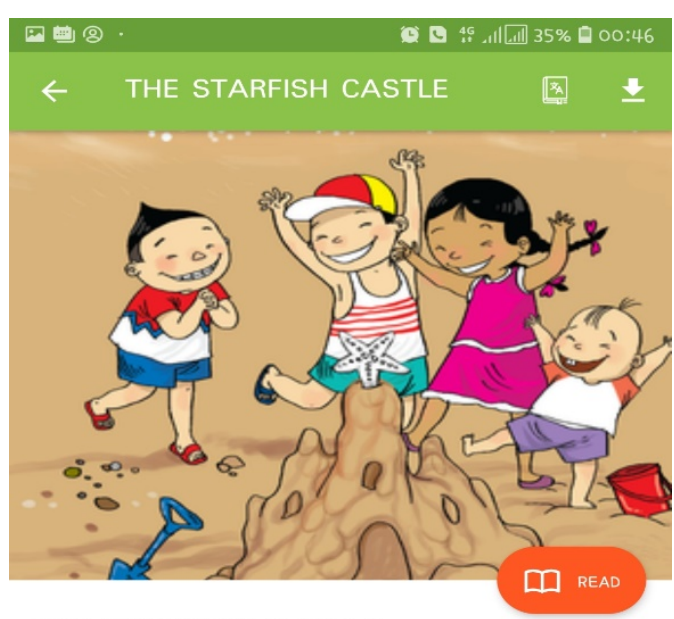

THE STARFISH CASTLE

\section{Reading Level: Level 2}

One day, the kids built the most beautiful castle ever on the beach

Original Work

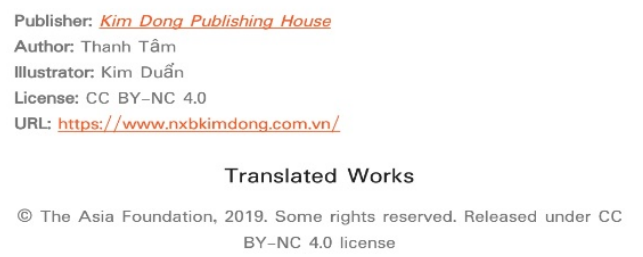

Figure 5. Cover Page 


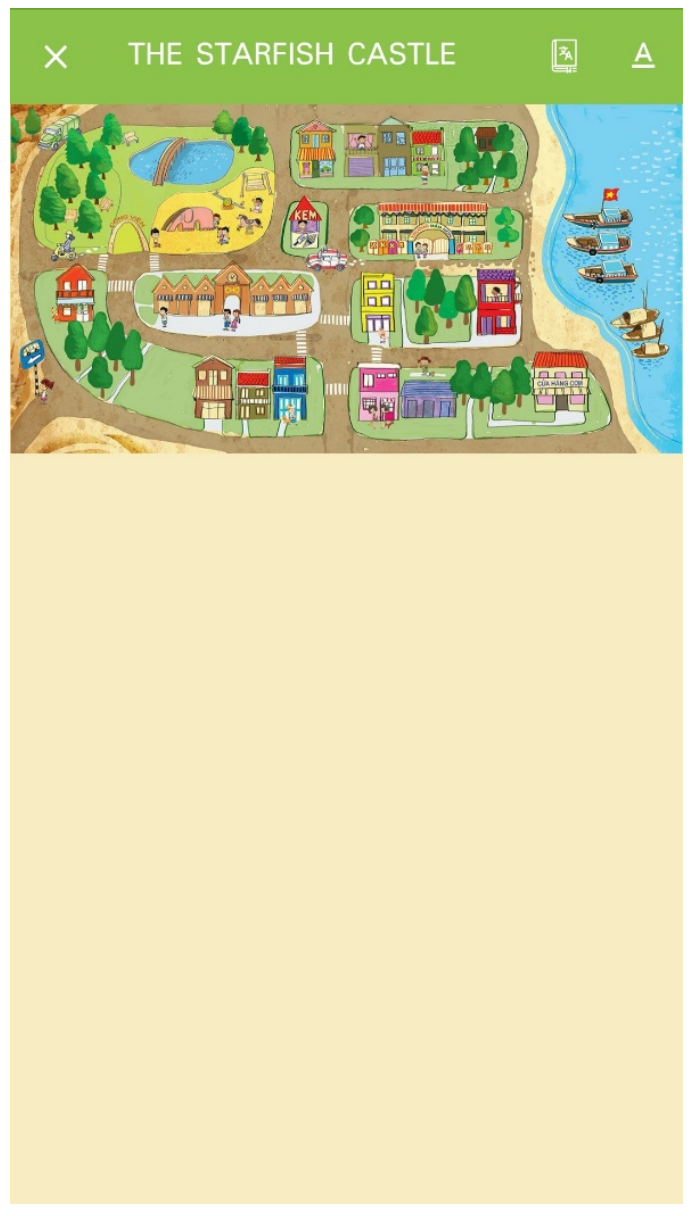

Figure 6. Prediction page

As suggested by Ellis (2009), task-based activities dedicated for a languageteaching activity must satisfy the following criteria: (1) Meaning must become the main focus, (2) there must be gaps as the goal, (3) learners must largely have to rely on their own resources, (4) there is a clearly defined outcome other than the use of language. Facilitating language learning in the classroom, pedagogical tasks were

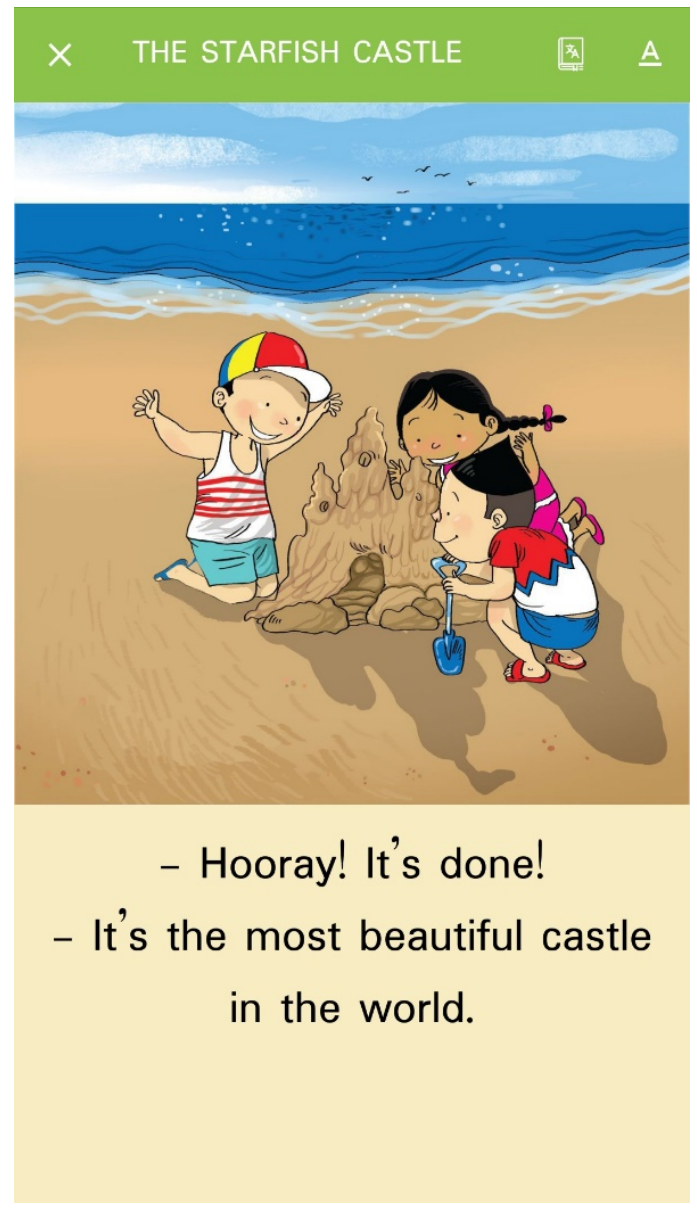

Figure 7. The Story Page

derived from Bamford and Day (2004) as the extensive reading activities.

Reading activities are designed to motivate the reading class. The following table shows the steps of the tasks applied in an elementary classroom for a week (day 1-6), including opinion-exchange task, reasoning-gap task, information-gap task, and mission-completing task (Chen, 2018). 
Table 1. Weekly-Task-Based Activities in Extensive Reading Class

\begin{tabular}{|c|c|c|}
\hline הכור & Pre-Tasks & Interactive Tasks \\
\hline $\begin{array}{l}\text { Day } 1 \\
\text { Making Prediction } \\
\text { (Reasoning-Gap Task) }\end{array}$ & $\begin{array}{l}\text { Students read the teacher- } \\
\text { selected book and } \\
\text { prepared answers to the } \\
\text { questions (e.g. What do } \\
\text { you think about the } \\
\text { situation around the main } \\
\text { character?) }\end{array}$ & $\begin{array}{l}\text { Students predicted the } \\
\text { situation in the story. In } \\
\text { groups of four, they sought } \\
\text { to share their ideas, and } \\
\text { check it if their predictions } \\
\text { were logical. Presenting the } \\
\text { illustration of the } \\
\text { surrounding is also } \\
\text { recommended. }\end{array}$ \\
\hline $\begin{array}{l}\text { Day } 2 \\
\text { Oral Interview } \\
\text { (Information Gap Task) }\end{array}$ & $\begin{array}{l}\text { Students read self- } \\
\text { selected digital books from } \\
\text { Let's Read! and prepared } \\
\text { to answer the questions as } \\
\text { if they were the main } \\
\text { characters in the stories } \\
\text { (e.g. What happened to } \\
\text { you? Why did you act so? } \\
\text { How did you describe your } \\
\text { best friend in this story?) }\end{array}$ & $\begin{array}{l}\text { One student acted as the } \\
\text { main character, and the } \\
\text { rest of group members } \\
\text { acted as interviewers who } \\
\text { tried to find out the events } \\
\text { in the story. The teacher } \\
\text { invited students to tell the } \\
\text { stories that sounded } \\
\text { interesting in the front of } \\
\text { the classroom. Interviewers } \\
\text { are also asked to } \\
\text { contribute some } \\
\text { suggestions to solve the } \\
\text { main character's problems. }\end{array}$ \\
\hline $\begin{array}{l}\text { Day } 3 \\
\text { A Different Ending } \\
\text { (Opinion-Exchange Task) }\end{array}$ & $\begin{array}{l}\text { Students read self-selected } \\
\text { digital books from Let's } \\
\text { Read! and created endings } \\
\text { for the stories. }\end{array}$ & $\begin{array}{l}\text { Firstly, Students in groups of } \\
\text { four summarized the stories, } \\
\text { and then read the stories } \\
\text { with new endings to the } \\
\text { group. Students could also } \\
\text { be swapped to form new } \\
\text { groups, and they might } \\
\text { share other versions of how } \\
\text { stories end. }\end{array}$ \\
\hline $\begin{array}{l}\text { Day } 4 \\
\text { A Letter to one character } \\
\text { (Information-Gap Task) }\end{array}$ & $\begin{array}{l}\text { Students read self-selected } \\
\text { digital books from Let's } \\
\text { Read! and prepared to }\end{array}$ & $\begin{array}{l}\text { In pairs, each partner } \\
\text { narrated a plot from } \\
\text { different characters' point }\end{array}$ \\
\hline
\end{tabular}




\begin{tabular}{|c|c|c|}
\hline & narrate the story. & $\begin{array}{l}\text { of view in their stories. Each } \\
\text { partner then wrote } \\
\text { questions or comments to } \\
\text { the other partner's } \\
\text { character in the form of a } \\
\text { letter. Students then read } \\
\text { the letter to the class, and } \\
\text { responded to the questions } \\
\text { or comments written in the } \\
\text { letter. }\end{array}$ \\
\hline $\begin{array}{l}\text { Day } 5 \\
\text { Reading Marathon I } \\
\text { (Mission-Completing Task) }\end{array}$ & $\begin{array}{l}\text { Teacher shared the } \\
\text { equivalence that } 1 \text { book }\end{array}$ & $\begin{array}{l}\text { Teacher provide a } \\
\text { template for recording the } \\
\text { books as well as the levels } \\
\text { and authors that the } \\
\text { students have read. }\end{array}$ \\
\hline $\begin{array}{l}\text { Day } 6 \\
\text { Reading Marathon II } \\
\text { (Mission-Completing Task) }\end{array}$ & $\begin{array}{l}\text { needed to read } 43 \text { books } \\
\text { to complete } 42,195 \mathrm{~km} \text { of } \\
\text { marathon 'running'. }\end{array}$ & $\begin{array}{l}\text { The students who read } \\
\text { more than } 5 \text { digital books } \\
\text { got rewards, and they } \\
\text { should pick a favorite book } \\
\text { to promote it to other } \\
\text { readers. }\end{array}$ \\
\hline
\end{tabular}

\section{CONCLUSION}

It was realized how important to meet the students in their online world, and to adjust teaching resources and activities to the 21 st century reading activities. In addition to accommodating the new generation of students (Z-Generations), the application of Let's Read!, in particular, also help to answer the issue of English graded reading sources. Task-based learning in extensive reading classroom brings a positive learning cycle among students. They applied L2 for real purposes, like telling stories, and exchanging information and opinions. Since students experienced interesting reading materials and meaningful tasks, they had positive exposures in language learning, it then motivated them to read more books, and develop reading habits gradually. This learning process supports how task-based activities in extensive reading class increases students' language development, and builds reading habits as promoted by GLS for the past three years. Another suggestion for supporting students' motivation and engagement is to give various task-based projects.

\section{Information-Gap Task}

In this stage, the students were invited to increase their awareness to the language focus presented in the reading source, 
and at the same time, they also formulated what their required lexical or tenses when they needed to retell or interview other fellows. Ellis (2008) states that completing a task, students think about and state their personal preferences, attitudes or feelings, which make them unconsciously apply the target language contextually.

In line with Ellis, Chen (2018) found that in the information-gap task, students use reason and logic to make predictions or inferences about the story. Such activity allows students to request information, ask for clarification, and learn to present the story in a logical sequence. At the same time, students' excitement getting further information about certain character in a story leads to class engagement. At the end of this task, students could also be invited to present their findings about those characters, or they could also be asked to choose their favourite character where they interviewed by stating the reasons.

\section{Opinion-Exchange Task}

An opinion-exchange task triggered "identifying and articulating a personal preference, feeling or attitude in response to the given situation" (Prabhu. 1987, p. 47). In opinion-exchange activities, parts of information were missing at the start, and participants negotiated until they completed the task. Sekhan (1998) in Green (2005) found that the process of target language's structure exploration occurred when the students are encouraged to negotiate meaning during the task-based reading activities. This process is possible to be applied during the post-reading activities as the wrap up of a reading time. Presenting different endings allows students to share with each other their new endings composed in an authentic creative speaking or writing activity.

\section{Reasoning-Gap Task}

The beneficial values proposed by taskbased activities in extensive reading class are that this approach supported students' cognitive development, and brought learning through interaction (Green, 2005). The activity of giving advice to the character, students worked together to solve the problems faced by the characters in the stories. The outputs of these tasks involved both written reports and oral presentations, which were prepared through students' collaboration and communication skills.

\section{Mission-Completing Task}

Making the activities more involving the students, graded-readers books are brought to classrooms, and the teacher set a task that students needed to complete a task of 'running for $42,195 \mathrm{~km}$ ' by reading 43 books. This activity invited students' feeling of achievement completing the tasks, which then motivated them to read more books, and gradually develop reading habits (Chen, 2018). In this postreading activity, students sought to work collaboratively as they should 'reach the finish line' with reading 43 books. 
Anesti Budi Ermerawati, The Application of Let's Read! in Extensive Reading Class...

Excitement will be obvious when students at the same time typed the book titles and the name of the author that they read on the class computer. Everybody can see their progress, and they will not realize that they actually were doing a task of reading, something that they said was boring before.

Working through task-based reading activities on the daily GLS program, students were encouraged to not only create reading habit in order to prepare themselves as lifelong learners, but also solve the linguistics problems beyond their individual abilities together. As Smith's (1971) Whole-Language Approach remark, natural acquisition of literacy could possibly happen without systematic instruction on the language features. Another support is Krashen's Input Hypothesis (1993) that claims that the more input a language teacher provides, the better the students could comprehend. In terms of collocation achievement, Amirabadi \& Marashi (2017) found that students having information-gap repeatedly benefit lexical collocation achievement. Lexical collocation is performed when students cannot communicate successfully, because they only focus on individual words without being aware of which words can be combined with them (Nesselhauf, 2003). Doing this activity, students will need to read from many sources that makes them grow alarm in the way of their formulating new words.
As extensive comprehensible input for children, positive impacts are found (Elly, 1991). The findings are in line with the objectives of the study. Furthermore, critical thinking skills that they need in solving problems should also be promoted, as the reading-thinking-sharing experience promotes the $21^{\text {st }}$ century students collaboratively construct knowledge through social interaction (Ellis, 2000).

In conclusion, by having weekly taskbased extensive reading activities as designed, it is assumed that the students will gain both language skill progress and positive attitude towards reading. It is hoped that some elementary English classes would apply task-based reading activities, so that students will carry reading habit during their lifelong learning. It is then eventually a basic need for the students to be literate in language literacy, numeracy literacy, financial literacy, scientific literacy, ICT literacy, as well as culture and civic literacy as they grow older

\section{REFERENCES}

Day, R. R., \& Bamford, J. (2004). Extensive Reading Activities for Teaching Language. Cambridge: Cambridge University Press.

Chen, I. (2018). Incorporating Task-Based Learning in An Extensive Reading Programme. ELT Journal, 72(4), 404414. doi:10.1093/elt/ccy008

Cho, K-S. \& Krashen, S. (2019). Pleasure Reading in a Foreign Language and Competence in Speaking, Listening, Reading, and Writing. TEFLIN Journal, 30(2).

http://dx.doi.org/10.15639/teflinjournal .v30i2/231-236. 
Faizah, D. U., Sufyandi, S., Anggraini, L., Waluyo, Dewayani, S., Muldian, W. \& Roosaria, D. R. (2016). Panduan Gerakan Literasi Sekolah. Jakarta: Direktorat Jenderal Pendidikan Dasar dan Menengah Kementerian Pendidikan dan Kebudayaan. ISBN: 978-602-1389-16-4.

Green, C. (2005). Integrating Extensive Reading in The Task-Based Curriculum. ELT Journal. 59(4), 306-11.

Iswandari, Y., \& Paradita, L. (2019). Extensive Reading in EFL Setting: A Special Interview with Professor Paul Nation. TEFLIN Journal. 30(2). http://dx.doi.org/10.15639/teflinjournal .v30i2/187-196.

Jones, F. R. (1998). Self-Instruction and Success: A Learner-Profile Study. Applied Linguistics, 19(3).

Kirkwood, A. (2008). Getting It from the Web: Why and How Online Resources are Used by Independent Undergraduate Learners. Journal of Computer Assisted Learning, 24(5).

Kondo M. (2015). An EFL Flipped Learning Course Design: Utilizing Students' Mobile Online Devices. Retrieved from https://research-

publishing.net/display_article.php?doi $=10.14705 /$ rpnet .2015 .000343

Krashen, S. (1993). The Power of Reading: Insights from the Research (Second edition). Portsmouth, NH: Heinemann.

Marashi, H., \& Amirabadi, S. (2017). The Impact of Information-Gap and Opinion-Gap Tasks on EFL learners' Lexical Collocation Achievement. International Journal of Educational Investigations, 4(2), 28-38
Nesselhauf, N. (2003). The Use of Collocations by Advanced Learners of English and Some Implications for Teaching. Applied Linguistics, 24(2), 223-42.

Oblinger, D. (2003). The Next Generation of Educational Engagement. Journal of Interactive Media in Education.

Piaget, J. (1963). The Origins of Intelligence in Children. New York: W.W. Norton \& Company, Inc.

Poláková, P., \& Klímová, B. (2019). Mobile Technology and Generation Z in the English Language Classroom - A Preliminary Study. Educational Sciences, 9-23. doi:10.3390/educsci9030203

Prabhu, N. S. (1987). Second Language Pedagogy. Oxford: Oxford University Press.

Prensky, M. (2007). Digital Natives, Digital Immigrants part 1. Retrieved from http://www.marcprensky.com/writing/ Prensky\%20\%20Digital\%20Natives,\%20D igital\%20lmmigrants\%20-\%20Part1.pdf

Scarborough, H. S. (2001). Connecting Early Language and Literacy to Later Reading (Dis) Abilities: Evidence, Theory, and Practice. In S. Neuman \& D. Dickinson (Eds.), Handbook for research in early literacy (pp. 97-110). New York: Guilford Press.

Trelease, J. (1997). The Read Aloud Handbook. New York: Penguin Books. 